\title{
Saving Forests for Wildlife in Brazil
}

\section{By Paulo Nogueira-Neto}

In Sao Paulo State in Brazil, 85 per cent. of the forests have been felled, mostly in this century, to make way for agriculture. As it is in the tropical forest that most of the wildife is found efforts are now concentrated on preserving the remnant and the wildlife with it. The author, who is a member of the State Forest Council and President of the Association for the Defense of the Flora and Fauna, lists the mammals and birds in danger of extermination and describes some of the $\mathbf{3 5}$ state forests and seven state parks already established.

THE state of Sao Paulo, although not one of Brazil's largest, is practically the size of Great Britain. It consists mostly of highland rolling country, some $2000 \mathrm{ft}$. above sea level, with two high mountain ranges: the steep Serra do Mar near the Atlantic coast, and the Serra da Mantiqueira in the interior. Most of Brazil's production and wealth is concentrated in this one state, which has a population of 12 million.

The Serra do Mar range is covered mostly by large and spectacular tropical rain forests, which owe their preservation largely to the steepness of the mountain slopes. The state owns several large forest reserves here, but in privately owned areas the forests are slowly being threatened by creeping banana plantations and charcoal exploitation.

In the highlands there are two types of forest: a tropical semideciduous forest, with tall trees, which is being decimated by the rapid advance of agriculture, and the "cerrado" forest, a transition between a low forest and a savanna, found on poor soils, which covers the last large open spaces in the interior. Practically all of it has been cut several times, but it regenerates quickly, in 10 or 15 years. In some high and cool mountain valleys of the Mantiqueira range, 6,000 ft. up, there is another type of forest, now rare but well preserved, consisting mostly of Araucaria angustifolia, a remarkable T-shaped conifer. All these four major types of forest are represented in the state parks and forests, although very few cerrados are preserved.

The expansion of agriculture, especially in the last 60 years, has led to the destruotion of some 85 per cent. of the primitive forests in which most of our wild animals live. The Association for the Defense of Flora and Fauna has therefore deoided to concentrate its efforts on preserving the remnant. If these are preserved the animals will be reasonably safe. It is very difficult for hunters to exterminate a species inside a large Brazilian tropical forest, especially in a mountain range. Most of the animals are small, and generally they can very well take care of themselves.

Three mammals and four birds are in danger of extinction in Sao Paulo today. The mammals are the jaguar, the large cervo deer 
Edocerus dicotomus and a spider monkey Brachyteles arachnoides; the birds are the avinhado Oryzoborus angolensis, a canary-sized finch, wine and black coloured; the bicudo $O$. crassirostris maximiliani, another finch somewhat bigger than the avinhado; the jacutinga Pipile jacutinga, a gallinaceous game bird, and the araras-macaws-which, however, are more numerous in other Brazilian states.

The avinhado is a highly prized cage bird, and prices range up to 100 dollars per bird, and even 400 dollars. Although still found in swampy places, on the borders of forests, its numbers are declining at an alarming rate. The bicudo is practically gone from S. Paulo, and seriously menaced in other states. Both these finches are wonderful singers and easy to capture. Some efforts are being made to raise the avinhado in captivity, but it is not yet known whether this will succeed. Recently a national song contest of these birds was held in Brasilia and received much publicity.

Macaws require very large forests, or cerrado bush savannas, with little disturbance. Unfortunately, they are not found in Serra do Mar. It is difficult to see how they can be saved here since hunting laws are difficult to enforce on all privately owned land. However, there is a chance that they may survive in the large Morro do Diabo State Forest. The jacutinga, a game bird the size of a large pheasant, will probably be safe in the state forests and parks of the Serra do Mar range. But it is easily hunted, and its tameness has been the cause of its disappearance over large areas.

\section{Some Mammals}

The jaguar, a very rare animal, requires large forests, perhaps more than 25,000 hectares $(1$ hectare $=2.47$ acres). In the forests of the Serra do Mar there is a smaller and little known race, which may be safe there although few in numbers. The jaguar may also survive in the Morro do Diabo Forest.

The spider monkey is the largest primate in Brazil and lives in small bands in the Serra do Mar. It is said to be very easily hunted. Dr. Avila Pires has reported a few in Angra dos Reis, in the state of Rio de Janeiro bordering on S. Paulo, and Dr. Raul Loeb told the author that it still exists in the region of Eldorado (Xiririca). A survey is needed to establish its distribution.

The cervo deer is still found in small numbers in some areas. There may be a few near Lagoa Sao Paulo in the west. The problem is that this deer lives in open savannas bordering large marshes, and there is no state park or reserve with large areas of this type of habitat. In other parts of Brazil the cervo is still protected by some ranchers who take pride in its preservation.

The Sao Paulo state forests are reasonably well kept, and the necessity of preserving them is recognised by the authorities and many of the people. The head of the Forest Service, eng. agr. Roberto de Mello Alvarenga, works hard for their protection, and the state spends more on its forests than all the rest of Brazil put together. The regular 
State Forest Guards are supplemented by a Forest Police with 850 serving soldiers and officers. This has proved of great value in emergencies, as when the forests were seriously threatened with invasion by settlers. But their military training has little connection with wildlife and forest problems, and they are not efficient as forest keepers. The money spent on them could be better used on fewer but more specialised personnel.

\section{State Forests and Parks}

The 35 state forests cover 186,045 hectares, and seven state parks comprise 72,393 hectares, and the numbers of both are continually increasing. Most are well established; others still include private land, and in some the legal situation is now being argued in the courts. Probably the most remarkable are those of Morro do Diabo, Campos do Jordao, Itatins, Piracicaba, Porto Ferreira, Serra da Cantareira and Cardoso Island.

Morro do Diabo (37,156 hectares), in Sao Paulo's far west, has a large mesa formation, somewhat like a giant watermelon soaring above the surrounding highlands. I flew over it and found it most impressive. It is of the greatest importance for the preservation of several of the species already mentioned. In the west, including the region round Morro do Diabo, the tall, quick-growing coloniao grass Panicum maximum presents a difficult problem, for it penetrates into the outskirts of the forests and easily catches fire, killing many trees, after which the grass advances still further. Only intensive efforts will check this.

Campos do Jordoa (8,132 hectares), a mountain winter resort, $6,000 \mathrm{ft}$. up in the Mantiqueira Mountains, has most of Sao Paulo's last stands of Auraucaria angustifolia. Itatins (12,058 hectares), near the coast, has several impressive granite-gneiss peaks, emerging through the tropical rain forest, an unforgettable sight from the air. Piracicaba (76 hectares) and Porto Ferreira ( 800 hectares), are among the best remnants of the tropical semi-deciduous forest. Both reserves have stands of the very high, large and majestic jequitiba tree, king of our forests and now rare. Serra da Cantereira (4,500 hectares), close to the city of S. Paulo, one of the few tropical forest parks in the world on the outskirts of a large city, is mostly secondary growth, but has some virgin stands. It illustrates well the principle that in a large tropical forest in a rugged territory, most small animals can survive in spite of poachers.

Most of the Cardoso Island State Park (13,000 hectares) is still in private hands, but very few people live there and 95 per cent. of the land is uncultivated. A channel, nowhere more than three kilometres wide, separates it from the mainland. The high mountain peaks, covered by an impressive tropical rain forest, soar to 890 metres. The land is cheap, and if the necessary funds were available to buy it, and international organisations were interested, this beautiful and primitive island might be the ideal place to save the orang utan and other 
threatened tropical animals. In a country like Brazil, where so many vital things still wait to be done, funds for preservation purposes are scarce. But over the years the state of Sao Paulo has bought private land and is slowly enlarging its forest reserves, and saving their animals with them.

\section{Acknowledgments}

The author wishes to thank the State Forest Service and others mentioned in this article for data supplied; also Mr. José Carlos Reis de Magalhaes, for his suggestions, and the editor for revising the English.

\section{READ \\ AUDUBON MAGAZINE}

America's popular, authentic and educational nature publication. Leading writers and photographers. Subscription rate $\$ 7.00$ per year for 6 colourful issues.

\section{NATIONAL AUDUBON SOCIETY \\ 1130 FIFTH AVENUE NEW YORK, N.Y. 10028}

\section{THE FPS TIE}

Navy blue, dark green or maroon Terylene with Oryx heads in white.

$£ 1$ each post free from

C. H. MUNDAY LTD.

7 Irving Street, Leicester Square,

London, WC2. Tel. Whitehall 1318 